\title{
Inflamed vermiform appendix within the sac of incarcerated left inguinal hernia
}

\author{
Boğulmuş sol kasık fitığı içinde inflame vermiform apendiks
}

\author{
Sevim TURANLI, Murat Ulvi YÜKSEL, Yavuz PİRHAN, Abdullah ÇETİN
}

\begin{abstract}
A 54-year-old male complained of a continuous pain together with an irreducible swelling of the left inguinal region 8 hours prior to admission to the surgical emergency department. His physical examination revealed a very painful, erythematous, irreducible swelling in the left inguinal region without abdominal peritoneal irritation. Routine blood tests disclosed mild leukocytosis. Abdominal plain X-ray film was not specific, and ultrasonography revealed a $10 \mathrm{~cm}$ in length inactive, edematous intestinal section within the inguinal hernia. With the diagnosis of strangulated inguinal hernia, he underwent surgical exploration through a transverse inguinal incision. By opening the hernia sac, 6-8 cc inflammatory fluid drained out, and an inflamed vermiform appendix adhered to the inner surface of the sac was seen. Appendicectomy and primary hernia repair were performed at the same time through the inguinal incision. The postoperative course was uneventful, and the histological examination of the specimen revealed an inflamed appendix.
\end{abstract}

Key Words: Amyand's hernia; left side; surgical treatment.
Elli dört yaşında erkek hasta, 8 saat önce başlayan sol kasıkta sürekli ağrı ve redükte olmayan şişlik şikayeti ile acil cerrahi servisine başvurdu. Fiziksel incelemede karında hassasiyet yoktu, sol kasıkta oldukça ağrılı, eritemli ve redükte olmayan şişlik vardı. Rutin kan testlerinde hafif lökositoz saptandı. Düz karın grafisinde özellik yoktu, ultrasonografide sol inguinal kanalda $10 \mathrm{~cm}$ uzunluğunda, hareketsiz, ödemli ince bağırsak ansı görüldü. Boğulmuş sol kasık fitığı tanısıyla hasta ameliyata alınd1. Kasığa transvers kesi yapılarak fitık kesesi ortaya konuldu. Kese açıldığında 6-8 cc pürülan sıvı geldi, vermiform apendiks inflame ve kese iç duvarına yapışık durumdayd1. Aynı seansta hem apendektomi hemde primer fitık onarımı yapıldı. Ameliyat sonrası komplikasyon gelişmedi. Patolojik inceleme inflame apendiks ile uyumluydu.

Anahtar Sözcükler: Amyand fitığı; sol taraf; cerrahi tedavi.
Acute abdomen syndrome due to inflamed or perforated vermiform appendix is very common and mostly diagnosed preoperatively. However, it does not come to mind if it is atypically localized. In 1735, Claudius Amyand was the first to define perforated appendix within the sac of an inguinal hernia while operating on a male patient who had a right inguinal hernia together with a fistula draining to the groin. ${ }^{[1]}$ Since then, the presence of a vermiform appendix in an inguinal hernia sac has been referred to as Amyand's hernia, and it remains a rare occurrence.

We point out the need to consider acute appendicitis in left-sided incarcerated inguinal hernia and we briefly review the literature on this topic.

\section{CASE REPORT}

A 54-year-old male was admitted to our surgical emergency department with an incarcerated inguinal hernia. In his medical history, he reported intermittent groin pain over the last six months and a sudden onset of a continuous pain together with an irreducible swelling of the left inguinal region 8 hours prior to admission. He was not experiencing disturbances of bowel function or symptoms such as anorexia, nausea, vomiting, or abdominal discomfort. Physical examination revealed a very painful, erythematous, irreducible swelling in the left inguinal region without abdominal peritoneal irritation. There was no bowel sound on the swelling and very few bowel sounds in 
the abdominal region on auscultation. Digital rectal examination revealed no pathological findings. Routine blood tests disclosed mild leukocytosis. Urinary analyses were normal. Abdominal plain X-ray film was not specific and ultrasonography revealed a $10 \mathrm{~cm}$ in length inactive, edematous intestinal section within the inguinal hernia. With a diagnosis of strangulated inguinal hernia, he underwent surgical exploration through a transverse inguinal incision. The inguinal canal itself was found to be edematous. On opening the hernia sac, 6-8 cc inflammatory fluid drained out, and an inflamed vermiform appendix adhered to the inner surface of the sac was seen (Fig. 1). The omentum and base of the cecum had closed the deep inguinal orifice. Appendicectomy and primary hernia repair were performed at the same time through the inguinal incision. The postoperative course was uneventful, and the histological examination of the specimen revealed an inflamed appendix.

\section{DISCUSSION}

Incarcerated groin hernia is very common among patients who are admitted to the emergency surgery department. The omentum majus or small bowel is usually found in the hernia sac. However, certain unusual contents may also be encountered, such as the bladder, ovary, fallopian tube, large bowel diverticula with the form of diverticulitis or abscess, Meckel's diverticulum, a portion of the circumference of the intestine, or foreign bodies. Presence of vermiform appendix in the hernia sac is another rare situation, though because of normal anatomical localization of the vermiform appendix, it may logically be present in the right inguinal hernia sac. However, left-sided Amyand's hernia is also defined as a highly rare situation $^{[2-4]}$ and may be associated with situs inversus,

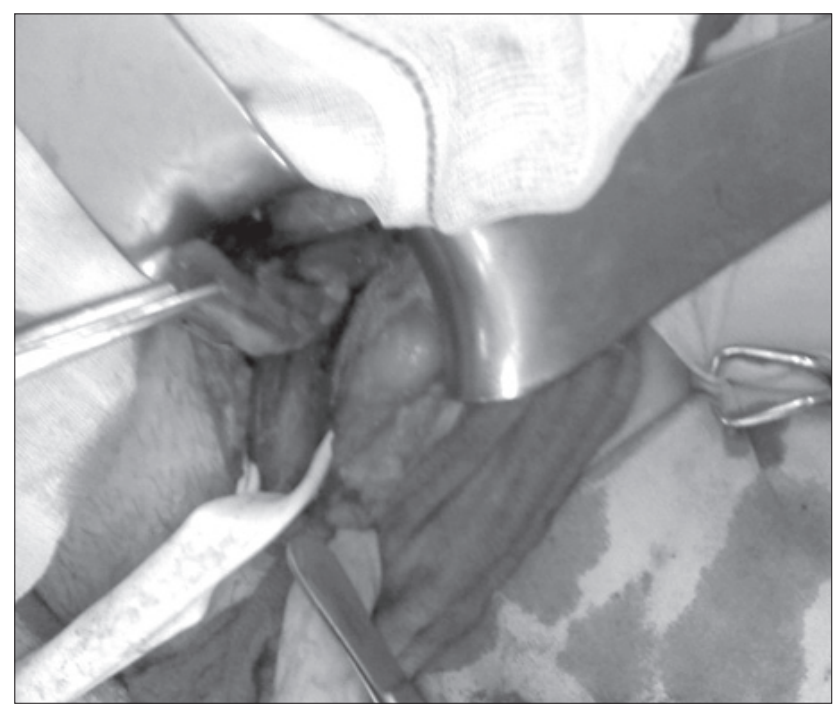

Fig. 1. The view of the vermiform appendix in the operating room. intestinal malrotation or mobile cecum. ${ }^{[5]}$ Amyand's hernia is also seen in neonates or children ${ }^{[6,7]}$ as well as adults, and is more frequent in males. ${ }^{[8]}$

When patients diagnosed as Amyand's hernia are examined retrospectively, the absence of acute abdominal symptoms is determined in most of them. Although there is an inflamed or perforated appendix, symptoms and signs are only on the hernia sac localization. ${ }^{[2,9,10]}$ It is usually misdiagnosed as an irreducible or strangulated inguinal hernia, acute hydrocele, acute epididymitis, testicular torsion, Richter's hernia, or inguinal lymphadenitis. ${ }^{[4]}$ As a result, any patient with painful swelling of the inguinal region, especially when accompanied by inflammation of the surrounding soft tissue, should raise suspicion of Amyand's hernia.

Ultrasonography is not adequate for a clear diagnosis, and preoperative abdominal tomography is performed only in certain situations to determine some other diagnoses. Some published cases were diagnosed by tomography preoperatively. ${ }^{[11,12]}$ The correct diagnosis is important if emergent surgery is indicated for deciding the form of incision. Inguinal incision is applied in most of the patients because Amyand's hernia is usually diagnosed intraoperatively. The selection of surgical intervention is based on the presence or absence of inflammation of the appendix in the sac. If the vermiform appendix is not inflamed, the common approach is to not perform appendectomy. Peritoneal contamination in the abdomen may lead to laparotomy, where appendectomy together with hernia repair is sufficient if the inflammation or abscess in the vermiform appendix is confined to the hernia sac. ${ }^{[6,9]}$ In the present case, the patient had no abdominal discomfort, and although inflammatory fluid was seen in the sac, the cecum and omentum had tightly closed the deep inguinal orifice, so laparotomy was not needed.

Repair of Amyand's hernia with prosthetic mesh is controversial. Some authors claim the use of prosthetic mesh is not suitable due to the contaminated operating field ${ }^{[8,10,13,14]}$ while others say that primary hernia repair could be difficult in an inflamed and edematous area, and could thus increase the risk of recurrence. ${ }^{[8]}$ In our patient, edema and inflammation were present in the field though primary repair was possible, and we did not prefer prosthetic mesh repair.

The physiopathology of Amyand's hernia is unknown. One of the theories is that following increased intraabdominal pressure for any reason, the vermiform appendix is compressed in the inguinal canal, which leads to poor blood supply and bacterial overgrowth, inflammation and subsequent perforation. ${ }^{[15]}$ Another theory is that Amyand's hernia with acute appendicitis is an incidental finding. ${ }^{[16]}$ 
In conclusion, preoperative diagnosis of appendicitis in an inguinal hernia, especially on the left side, requires high clinical suspicion. The choice of surgical procedure depends on the presence or absence of appendicular inflammation. If the vermiform appendix is normal, hernia repair alone is sufficient. The inflammatory status of the appendix determines the type of hernia repair and the surgical approach.

\section{REFERENCES}

1. Hutchinson R. Amyand's hernia. J R Soc Med 1993;86:1045.

2. Gupta S, Sharma R, Kaushik R. Left-sided Amyand's hernia. Singapore Med J 2005;46:424-5.

3. Breitenstein S, Eisenbach C, Wille G, Decurtins M. Incarcerated vermiform appendix in a left-sided inguinal hernia. Hernia 2005;9:100-2.

4. Carey LC. Acute appendicitis occurring in hernias: a report of 10 cases. Surgery 1967;61:236-8.

5. Bakhshi GD, Bhandarwar AH, Govila AA. Acute appendicitis in left scrotum. Indian J Gastroenterol 2004;23:195.

6. Livaditi E, Mavridis G, Christopoulos-Geroulanos G. Amyand's hernia in premature neonates: report of two cases. Hernia 2007; 11:547-9.

7. Martins JL, Peterlini FL, Martins EC. Neonatal acute appendicitis: a strangulated appendix in an incarcerated inguinal hernia. Pediatr Surg Int 2001;17:644-5.
8. Torino G, Campisi C, Testa A, Baldassarre E, Valenti G. Prosthetic repair of a perforated Amyand's hernia: hazardous or feasible? Hernia 2007;11:551-4.

9. Kueper MA, Kirschniak A, Ladurner R, Granderath FA, Konigsrainer A. Incarcerated recurrent inguinal hernia with covered and perforated appendicitis and periappendicular abscess: case report and review of the literature. Hernia 2007;11:189-91.

10. Salemis NS, Nisotakis K, Nazos K, Stavrinou P, Tsohataridis E. Perforated appendix and periappendicular abscess within an inguinal hernia. Hernia 2006;10:528-30.

11. Ash L, Hatem S, Ramirez GA, Veniero J. Amyand's hernia: a case report of prospective ct diagnosis in the emergency department. Emerg Radiol 2005;11:231-2.

12. Luch JS, Halpern D, Katz DS. Amyand's hernia: prospective CT diagnosis. J Comput Asist Tomogr 2000;24:884-6.

13. D'Alia C, Lo Schiavo MG, Tonante A, Taranto F, Gagliano E, Bonanno L, et al. Amyand's hernia: case report and review of the literature. Hernia 2003;7:89-91.

14. Sharma H, Gupta A, Shekhawat NS, Memon B, Memon MA. Amyand's hernia: a report of 18 consecutive patients over a 15-year period. Hernia 2007;11:31-5.

15. Abu-Dalu J, Urca I. Incarcerated inguinal hernia with a perforated appendix and periappendicular abscess: report of a case. Dis Colon Rectum 1972;15:464-5.

16. Bar-Maor JA, Zeltzer M. Acute appendicitis located in a scrotal hernia of a premature infant. J Pediatr Surg 1978;13:1812. 